\title{
KOMPETENSI WIDYAISWARA DALAM MENGEMBANGKAN PRESENTASI INTERAKTIF ONLINE DENGAN APLIKASI MENTIMETER DI BALAI DIKLAT KEAGAMAAN PALEMBANG
}

\author{
Sri Sunarti ${ }^{1}$ \\ ${ }^{1}$ Balai Diklat Keagamaan Palembang \\ ${ }^{1}$ sribdk@gmail.com
}

Diterima: 7 Juli 2021 | Disetujui: 16 Juli 2021 ～Dipublikasikan : 18 Juli 2021

\begin{abstract}
Abstrak
Tujuan penelitian ini adalah untuk mengetahui bagaimana kompetensi widyaiswara dalam mengembangkan bahan ajar presentasi interaktif online dengan menggunakan aplikasi mentimeter. Aplikasi mentimeter adalah sebuah aplikasi online yang dapat mendesain materi pelatihan menjadi lebih menarik dan menyenangkan. Selain itu, mentimeter dapat dijadikan alat survei dan kuis online dalam pembelajaran jarak jauh atau e-learning. Penelitian ini merupakan penelitian kuantitatif dengan menggunakan instrumen dalam bentuk pertanyaan untuk mengetahui kompetensi widyaiswara dalam mengembangkan presentasi interaktif online dengan aplikasi mentimeter. Data diolah untuk mencari rata-rata kemampuan kompetensi widyaiswara. Setelah data diolah ditemukan bahwa sekitar $85 \%$ widyaiswara telah memahami bagaimana pemahaman widyaiswara tentang mentimeter dan beberapa kompetensi widyaiswara tentang mentimeter seperti, sekitar $24 \%$ widyaiswara yang kurang pemahaman tentang mentimeter, sekitar $24 \%$ widyaiswara lupa tentang penggunaan mentimeter, dan $52 \%$ widyaiswara menggunakan aplikasi lain dalam mendesain presentasi. $\quad$ (10, No Bold)
\end{abstract}

Kata Kunci: bahan ajar, presentasi interaktif, online, kompetensi widyaiswara, mentimeter

\begin{abstract}
[PENINGKATAN KOMPETENSI WIDYAISWARA DALAM MENGEMBANGKAN PRESENTASI INTERAKTIF ONLINE DENGAN APLIKASI MENTIMETER DI BALAI DIKLAT KEAGAMAAN PALEMBANG.] The purpose of this study was to determine how widyaiswara's competence in developing teaching materials of online interractive presentation by using the mentimeter application. The mentimeter application is an online application that can design training materials become more interesting and fun. In addition, the mentimeter could be used as a survey tool and online quiz in distance learning or e-learning. This study was a quantitatif research by used an instrument in the form of questions to determine the widyaiswara's competence in developing interactive online presentations with the mentimeter application. The data was counted to know the average of widyaiswara's competency. The result was about $85 \%$ of the widyaiswara have understood how the teaching materials for online interactive presentations with the mentimeter application and several knowledge of widyaiswara such as about $24 \%$ respondent reduced understanding of the mentimeter, about $24 \%$ respondent forgot about using the mentimeter, and about 52\% respondent used other applications in designing presentations.
\end{abstract}

Keywords: learning material, interractive presentations, widyaiswara's competency, mentimeter 


\section{PENDAHULUAN}

Widyaiswara sebagai narasumber utama dalam sebuah pelatihan, merupakan faktor kunci dalam kesuksesan sebuah pelatihan termasuk dalam mengatasi permasalahan yang sering muncul didalamnya. Mengingat urgennya peran widyaiswara dalam sebuah pelatihan, widyaiswara yang memiliki kompetensi yang unggul menjadi sebuah kebutuhan tiap lembaga diklat. Hal ini sangat sesuai dengan strategisnya peran yang diemban widyaiswara, yaitu sesuai Peraturan Menteri Pendayagunaan dan Aparatur Negara dan Reformasi Birokrasi Nomor 22 Tahun 2014 yang menyebutkan bahwa widyaiswara adalah Pegawai Negeri Sipil yang diangkat sebagai pejabat fungsional dengan tugas, tanggung jawab, wewenang, dan hak untuk melakukan kegiatan Dikjartih PNS, Evaluasi dan Pengembangan Diklat pada Lembaga Diklat Pemerintah. Dalam mengemban tugas tersebut, widyaiswara wajib memiliki kompetensi dalam pengelolaan pembelajaran, substansi, kepribadian dan sosial.

Untuk melaksanakan kegiatan pendidikan pengajaran dan pelatihan (dikjartih), widyaiswara harus mampu mendesain bahan ajar dengan baik dan menarik. Hal ini dikarenakan widyaiswara adalah seorang yang memiliki wawasan luas, dan menguasai informasi teknologi (IT) atau digital sehingga bisa dengan cepat mengupdate isu dan informasi secara online serta mampu bersaing ditingkat nasional, regional maupun global.

Seiring dengan perkembangan zaman dan teknologi saat ini, widyaiswara yang merupakan komponen penting dalam "transfer of competency" dituntut untuk dapat lebih aktif, kreatif dan inovatif dalam mendesain bahan ajarnya. Apalagi dengan adanya wabah covid 19 ini, mengakibatkan sebagaian besar pembelajaran dan pelatihan harus dilaksanakan secara online atau daring. Pembelajaran daring adalah pembelajaran yang menggunakan jaringan internet, dengan menggunakan aksesbilitas, konektivitas dan dan kemampuan untuk memunculkan berbagai jenis interaksi pembelajaran. Pembelajaran secara daring telah menjadi tuntutan saat ini terlebih dalam sebuah pelatihan. Materi dalam pelatihan harus dapat dikemas semenarik mungkin sehingga dapat meningkatkan motivasi peserta pelatihan dalam pembelajaran.

Pelatihan merupakan sebuah cara untuk merubah seseorang baik secara emosional maupun fisik. Ambar dan Rosidah (2003) mendefinisikan pelatihan adalah proses pendidikan jangka pendek dengan menggunakan prosedur sistematik tentang pengubahan perilaku para pegawai dalam satu arah guna untuk meningkatkan tujuan organisasi. Ini berarti pelatihan dalam jangka waktu yang tidak terlalu lama dengan jumlah jam 60 sampai dengan 100 jam pelajaran. Pada pelatihan, banyak mengedepankan praktik karena pendekatan pembelajaran dilakukan dengan pendekatan androgogi atau pembelajaran orang dewasa. Dengan mengikuti pelatihan, akan terjadi perubahan perilaku dan emosional pegawai menjadi lebih baik lagi sehingga mereka dapat bekerja dengan baik bersama tim.

Pelatihan yang efektif dan efisien adalah sebuah pelatihan yang memberikan praktek terhadap teori yang diketahui tentang tugas-tugas PNS. Menurut Rivai (2004), untuk menjadikan pelatihan efektif dan efisien, ada beberapa faktor yang menunjang efektivitas pelatihan, yaitu 1) materi atau isi pelajaran (disesuaikan dengan tugas, dan fungsi), 2) metode pelatihan (mempraktekkan metode pelatihan praktek, simulasi, dan diskusi), 3) Pelatih (narasumber/ trainer), 4) Peserta pelatihan (baik dari pegawai PNS, Non PNS ataupun guru), 5) Sarama pelatihan (jaringan internet, dan sarana lainnya yang mendukung pelatihan) dan 6) evaluasi pelatihan (blangko penilaian baik secara online maupun paper-based)

Setiap pelatihan yang telah dilaksanakan perlu dievaluasi untuk melihat kekurangan selama pelatihan dilaksanakan. Balai Diklat Keagamaan Palembang sebagai salah satu lembaga pelatihan harus dapat melaksanakan kegiatan pelatihan secara online. Berdasarkan rencana program BDK Palembang tahun 2021 sekitar 50\% kegiatan pelatihan dilaksanakan secara online atau pelatihan jarak jauh atau e-learning. Selaras 
dengan Perkalan Nomor 8 Tahun 2018 yang menyebutkan bahwa tahap penyelenggaraan e-learning sebagaimana dimaksud dalam Pasal 3 ayat (1), keseluruhan fasilitas dan mekanisme pelaksanaannya dilaksanakan dengan memanfaatkan media teknologi informasi dan komunikasi. Oleh sebab itu, widyaiswara dituntut untuk menguasai teknologi dan informasi (TI) dalam menyampaikan materi pelatihan karena pelatihan hanya boleh dilaksanakan oleh suatu lembaga pelatihan yang telah mendapatkan pengakuan dari Lembaga Administrasi Negara.

Dalam Perkalan Nomor 5 tahun 2008 menyebutkan bahwa widyaiswara harus mampu mengelola pembelajaran, salah satunya menyusun bahan ajar. Dalam hal ini, mengingat masa pandemi covid 19, bahan ajar yang diberikan kepada peserta tidak lagi secara langsung tetapi melalui e-learning. Mengingat pentingnya pelatihan dalam lembaga diklat maka widyaiswara harus mampu mengembangkan kemampuan kompetensinya dalam bidang teknologi informasi dan komunikasi. Namun, fakta dilapangan ditemukan bahwa masih ada widyaiswara yang belum mampu mengembangkan kompetensinya dalam mengembangkan bahan ajar menjadi sebuah presentasi yang lebih interaktif dan menarik. Apalagi dalam pembelajaran jarak jauh atau e-learning yang dilakukan secara online, perlu menjadikan pertemuan dan diskusi pelatihan menjadi lebih hidup dan aktif sehingga peserta tidak merasa bosan dan jenuh. Oleh sebab itu, widyaiswara perlu mendesain bahan ajarnya menjadi sebuah presentasi dalam bentuk yang lebih menarik, menyenangkan dan inovatif dalam pembelajaran jarak jauh.

Hal ini dibuktikan dari hasil penelitian Istiandaru dan Prabowo (2020) bahwa ada sekitar 11 guru mengaku sangat membutuhkan mentimeter, 10 guru dapat mengikuti pelatihan dengan sangat lancar dan 10 guru berminat menerapkan dalam pembelajaran. Artinya bahwa pelatihan tentang mentimeter ini membawa dampak positif terhadap peningkatan pengembangan profesional guru di SMP Muhammadiyah se-Yogyakarta. Ini berarti, aplikasi mentimeter dapat memberikan ketertarikan dalam pembelajaran terutama dalam pembelajaran jarak jauh maupun klasikal.

Pentingnya penerapan pembelajaran online dan face to face atau yang lebih dikenal dengan blendid learning dalam pelatihan membuat lembaga pelatihan harus mampu menguasai berbagai aplikasi pembelajaran online.

Banyak aplikasi presentasi yang dapat kita gunakan dalam mendesain bahan ajar. Beberapa aplikasi presentasi interaktif online yang dapat digunakan widyaswara yaitu seperti quiziz, padlet, zoom, mentimeter, slido, one note, emaze, libreoffice, google slide dan masih banyak lagi. Semua aplikasi tersebut bagus dan menarik. Setiap aplikasi memiliki kelebihan dan kelemahan. Kelemahan pelaksanaan pelatihan dalam sistem online ini yaitu seperti perlu adanya koneksi internet dan pemahaman tentang penggunaan aplikasi tersebut. Namun, untuk penelitian ini, peneliti menggunakan sebuah aplikasi presentasi interaktif online yang dapat digunakan dalam mendesain bahan ajar menjadi sebuah presentasi interaktif online yang menarik, inovatif dan menyenangkan yaitu aplikasi mentimeter.

Aplikasi mentimeter ini dipilih karena dalam pembelajaran jarak jauh dapat dijadikan sebuah cara interaktif dalam berdiskusi sekaligus tanya jawab sehingga widyaiswara dapat langsung menanggapi langsung dan memberikan penilaian kepada peserta pelatihan. Selain itu, widyaiswara mampu menghidupkan suasana menyenangkan saat pembelajaran berlangsung dengan memberikan kuis-kuis karena adanya timbal balik saat pembelajaran.

Aplikasi Mentimeter adalah salah satu software presentasi yang mudah digunakan untuk pelatihan jarak jauh sehingga hasil presentasi menjadi lebih interaktif, berkesan dan menyenangkan. Mentimeter juga dapat digunakan sebagai alat bantu dalam pelatihan untuk membuat quiz, polling, voting, soal baik pilihan ganda, esai, memasangkan sebagai brainstorming sebelum materi, tanya jawab dan sharing. Selain itu, mentimeter dapat digunakan juga 
melalui smartphone sehingga jawaban peserta dapat terhubung langsung dengan narasumber dalam tampilan yang menarik dan interaktif. Selain itu, hasil peserta dapat dianalisa secara langsung dan digunakan untuk mengukur program pelatihan yang telah dilaksanakan.

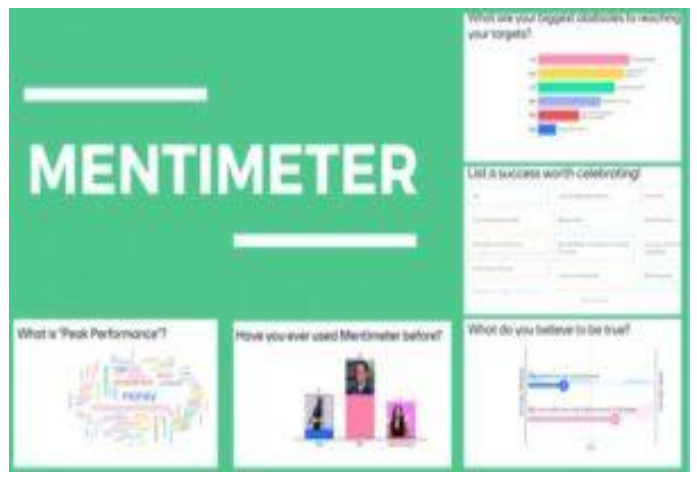

Gambar 1. Mentimeter

Menurut Rosidah (2020) menjelaskan bahwa mentimeter merupakan sebuah software dalam bentuk presentasi yang digunakan dalam pembelajaran, pelatihan, ceramah atau polling yang mudah, menarik dan cepat untuk digunakan. Aplikasi mentimeter memiliki tiga jenis slide yaitu pertama, Tipe pertanyaan popular (popular question types) yaitu slide yang berbentuk pertanyaan sehingga dapat dijadikan alat ukur untuk mengukur hasil belajar peserta dan mengumpulkan nilai serta tanggapan peserta pelatihan saat pembelajaran secara langsung ataupun dapat melempar pertanyaan ke peserta yang ditampilkan di slide materi widyaiswara.

Yang kedua adalah jenis slide quiz competitions, jenis slide ini digunakan untuk menghidupkan suasana pelatihan, dimana widyaiswara dapat membuat kuis ke peserta pelatihan sehingga dapat dijadikan semacam energizer atau warming up sebelum memulai materi atau saat ingin menghilangkan kebosanan saat belajar. Selain itu, saat di akhir slide mentimeternya akan ada rangking otomatis atau menampilkan skor tertinggi berdasarkan jawaban yang benar dan kecepatan peseta dalam mengerjakan kuis.

Ketiga, jenis slide quick slide yang berbentuk seperti powerpoint biasa dalam bentuk seperti paragraf, poin-poin, serta dapat mengunggah gambar atau video sehingga tampilan materi pembelajaran menjadi lebih minimalis dan simpel. Slide ini, berfungsi seperti powerpoint, widyaiswara dapat mendesain tampilan presentasi dengan model yang menarik. Tampilannya dapat berupa teks, gambar dan video atau animasi.

Ada satu jenis slide lagi yang sedikit lebih kompleks yaitu slide advances. Jenis ini untuk menilai dan memberi rating pada sebuah produk dan atau melakukan voting dengan 100 point, 2x2 grid, who will win, serta quick form.

Pada aplikasi mentimeter juga ada menu content yang berisi fitur setting atau editing dalam masing-masing type yang dipilih. Selain itu, menu customize yang berisi menu setting seperti (1) setting slide yang berisi pilihan pengaturan close voting, hide instructions bar, hide result. (2) layout, (3) image, (4) advanced layout dan (5) advanced color. Namun untuk menu yang ke 4 dan 5 hanya dapat digunakan pada mentimeter pro (berbayar).

Selain menu customize ada menu lain pada aplikasi mentimeter yaitu menu example, theme dan configure. Untuk masuk ke mentimeter ada beberapa langkah yang dapat kita lakukan yaitu, login ke mentimeter dahulu, lalu pilih jenis slide yang ingin dibuat. Selain itu, dapat disisipkan gambar yang sesuai dengan pertanyaan atau materi yang akan disampaikan. Untuk mengakses presentasi yang dibuat dapat mengetik menti.com dan memasukkan kode presentasi dan dibagikan ke peserta untuk ikut berpartisipasi.

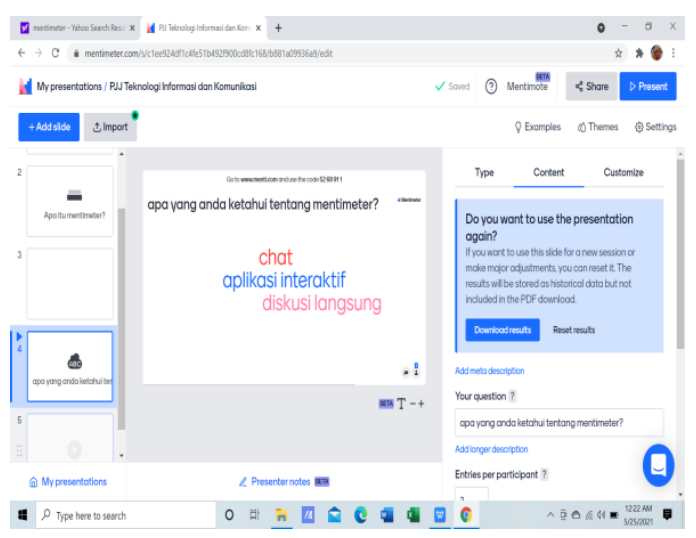




\section{Gambar 2 Bentuk Layout Mentimeter}

Selain membuka mentimeter secara sendiri yaitu memberikan no kode kepada peserta pelatihan mentimeter juga dapat disisipkan ke dalam slide power point yang telah dibuat dengan beberapa langkah sebagai berikut:

1) Buka slide powerpoint yang akan disisipkan ke mentimeter.

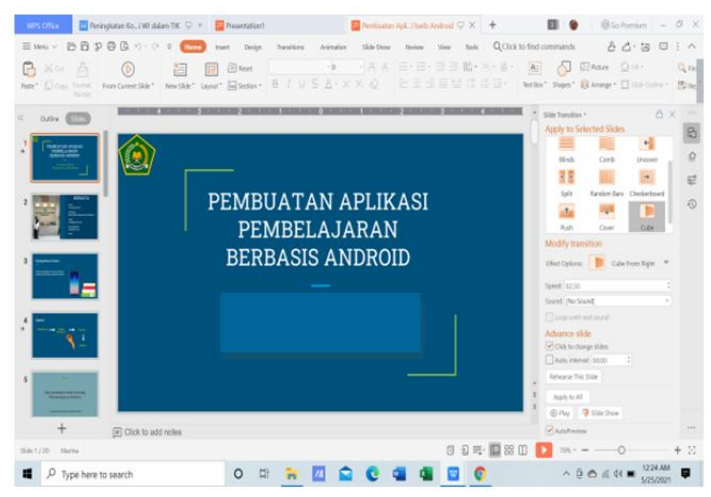

Gambar 2 Layout powerpoint

2) Pada slide powerpoint pilih menu insert Get Add-Ins pada kotak search ketikkan mentimeter lalu klik add lalu klik continue.

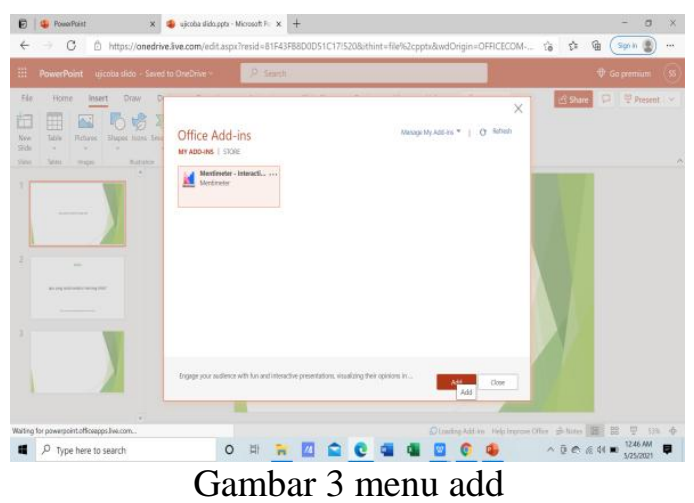

3) Setelah login ke akun mentimeter akan tampil slide powerpoint seperti dibawah ini, lalu pilih select

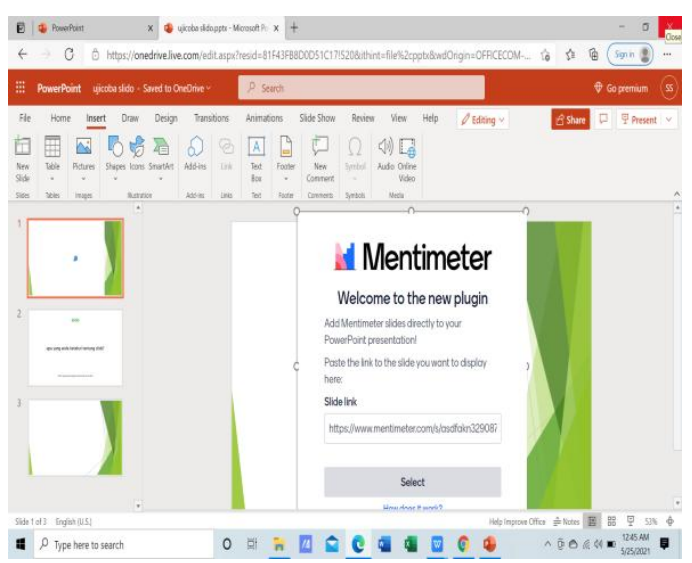

Gambar 4 layout awal mentimeter

4) Setelah itu buka slide mentimeter yang akan disisipkan.

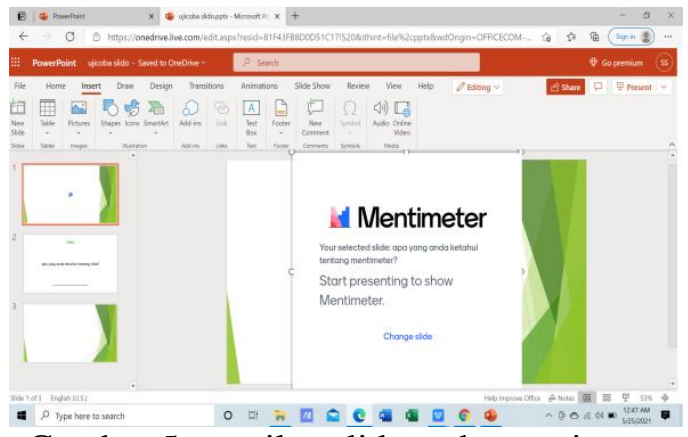

Gambar 5 tampilan slide pada mentimeter

5) Klik share presentation sharing pada bagian link to the live result, bisa pilih share, klik copy link lalu close, kemudian copy link untuk di bagikan di whatsapp ataupun email.

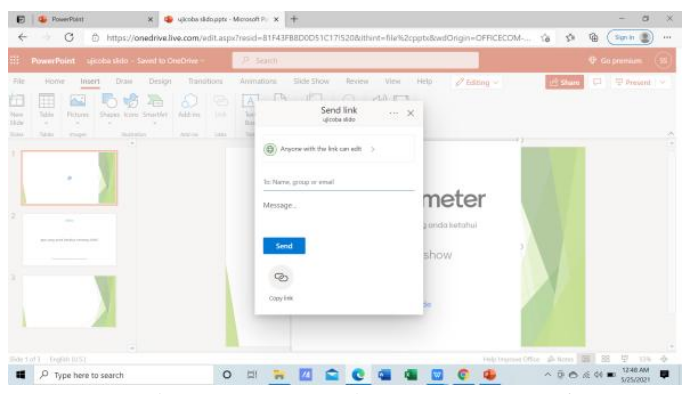

Gambar 6 menu share presentation

6) Buka kembali slide powerpoint pada slide link mentimeter, paste / pindahkan link slide mentimeter yang sudah di copy lalu tekan enter. 


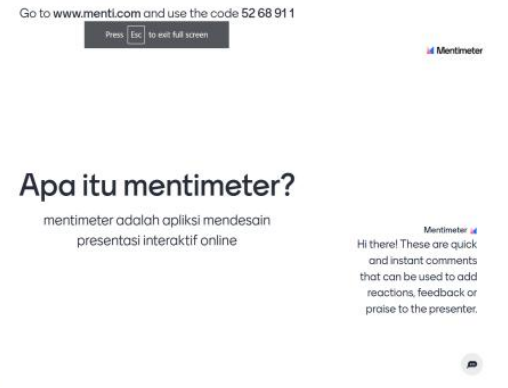

Gambar 7 layout mentimeter

7) Setelah itu tampilan powerpoint akan memperlihat tampilan yang serupa pada slide mentimeter yang telah disisipkan.

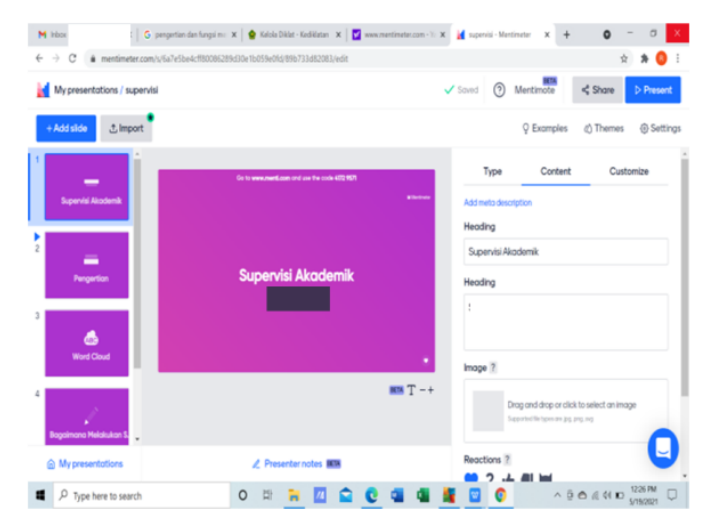

Gambar 8 Layout mentimeter setelah dimasukkan slide powerpoint

Menurut Eric (2021) mengemukakan beberapan kelebihan lain dari aplikasi mentimeter ini yaitu dengan aplikasi ini juga, tidak akan menghabiskan memori perangkat karena aplikasi ini digunakan secara online dan tersimpan di aplikasi online tersebut sehingga tidak perlu takut penuh atau hilang file yang telah kita buat. Selain itu, mentimeter juga dapat diakses melalui smartphone ataupun android, sehingga peserta pelatihan dapat belajar dimanapun.

Selain itu, dengan aplikasi mentimeter narasumber dapat berinteraksi langsung dengan peserta dengan memberikan slide khusus untuk diskusi dan tanya jawab selama pembelajaran sehingga dapat meningkatkan kualitas pembelajaran dan memantau secara langsung peserta yang ikut kegiatan pembelajaran karena adanya interaksi langsung antara narasumber dan peserta. Pembelajaran jarak jauh atau e-learning akan lebih mudah dengan menggunakan aplikasi mentimeter ini.

Dengan kata lain, aplikasi ini dapat menghidupkan suasana pelatihan karena narasumber dan peserta dapat berinteraksi langsung dengan narasumber serta mempermudah widyaiswara dalam menyampaikan materi dan berkomunikasi langsung dengan peserta diklat. Pada mentimeter, widyaiswara dapat memberikan penilaian hasil pelatihan secara langsung.

Melihat pentingnya mendesain presentasi interaktif online dalam pelatihan bagi widyaiswara maka peneliti mensurvei widyaiswara tentang pemahaman widyaiswara tentang aplikasi apa saja yang digunakan widyaiswara dalam mendesain bahan ajar. Selama ini, widyaiswara masih belum mengembangkan cara mendesain bahan ajar ke dalam presentasi interaktif. Widyaiswara hanya menggunakan program powerpoint 2007 atau 2016 dalam menyampaikan materi diklat kepada peserta pelatihan.

Hal ini dapat dibuktikan dari hasil survei kepada widyaiswara Balai Diklat Keagamaan Palembang bahwa 100\% widyaiswara hanya menggunakan aplikasi program powerpoint dalam menampilkan materi yang disampaikan sehingga kurang memberikan inovasi pada bahan yang akan ditampilkan dan disampaikan kepada peserta diklat. Selain itu, sekitar $71 \%$ widyaiswara yang memahami aplikasi presentasi interaktif lainnya selain powerpoint, widyaiswara yang memahami aplikasi lain dalam mengirim pesan sekitar $88 \%$, sekitar $82 \%$ widyaiswara yang pernah mendengar tentang aplikasi mentimeter, dan sebesar $88 \%$ widyaiswara mengharapkan adanya bimbingan teknis tentang bagaimana penggunaan aplikasi mentimeter pada bahan ajar. Untuk lebih jelasnya, dapat dilihat dari grafik berikut ini: 


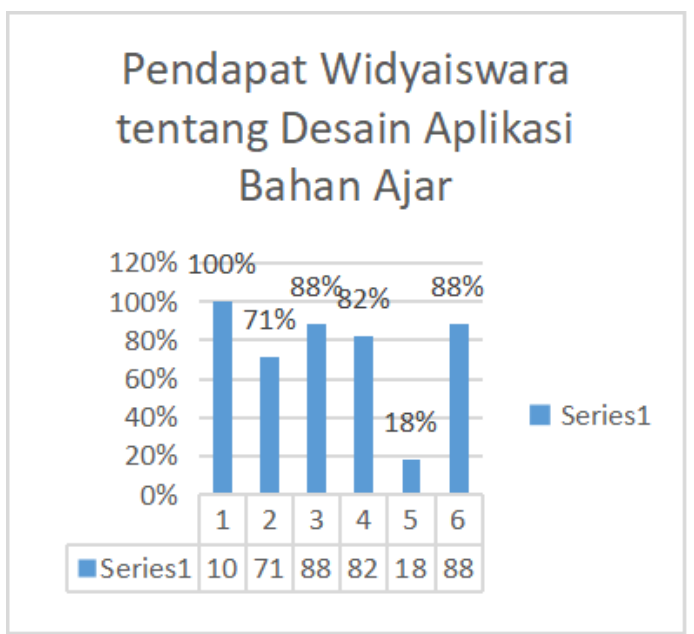

Gambar 3. Pendapat Widyaiswara tentang Desain Bahan Ajar

Keterangan:

1. apakah anda menggunakan powerpoint dalam menyampaikan materi?

2. Terkait dengan pekerjaan anda, apakah anda memahami beberapa aplikasi membuat presentasi interaktif selain powerpoint?

3. Apakah anda memahami beberapa aplikasi lain yang dapat digunakan untuk mengirim pesan dengan peserta pelatihan?

4. Apakah anda pernah mendengar aplikasi mentimeter?

5. Apakah anda memahami bagaimana membuat presentasi interaktif dengan menggunakan mentimeter?

6. menurut anda, sejauh mana keinginan anda ingin mempelajari mentimeter?

Dari hasil data diatas, maka dapat katakan bahwa selama ini widyaiswara belum mengembangkan bahan ajar menjadi sebuah presentasi interaktif online. Sebagian besar, widyaiswara Balai Diklat Keagamaan Palembang hanya menggunakan powerpoint dalam membuat presentasi. Hal ini dikarenakan keterbatasan pengetahuan dan kompetensi widyaiswara tentang berbagai aplikasi lain dalam mendesain presentasi interaktif online. Padahal, materi yang disampaikan widyaiswara sangatlah penting apalagi memberikan semangat dan menghidupkan suasana pembelajaran online bukanlah hal yang mudah. Oleh sebab itu, widyaiswara harus mampu mendesain pembelajaran menjadi aktif, kreatif, dan inovatif.
Berdasarkan uraian diatas, maka masalah dalam penelitian ini dapat dirumuskan sebagai berikut:

1. Bagaimana pemahaman widyaiswara tentang mentimeter?

2. Bagaimana kompetensi widyaiswara dalam menggunakan mentimeter?

Dari masalah-masalah diatas maka peneliti mengambil judul "Peningkatan kompetensi widyaisara dalam mengembangkan presentasi interaktif online dengan aplikasi mentimeter di Balai Diklat Keagamaan Palembang”.

\section{METODE PENELITIAN}

Penelitian ini merupakan penelitian deskriptif kuantitatif dengan menyebarkan instrumen kepada seluruh widyaiswara Balai Diklat Keagamaan Palembang. Instrumen tersebut disebar ke seluruh widyaiswara Balai Diklat Keagamaan Palembang dan dikumpulkan untuk dianalisis dan dihitung hasilnya.

1. Metode penelitian

Penelitian ini menggunakan metode ilmiah dengan memberikan kuesioner dan melihat hasil presentasi interaktif online yang dibuat oleh widyaiswara dengan menggunakan aplikasi mentimeter. Setelah itu, peneliti menghitung hasil instrumen yang disebar kepada seluruh sampel.

2. Populasi dan sampel

Yang menjadi populasi dalam penelitian ini adalah seluruh widyaiswara pada Balai Diklat Keagamaan Palembang yang berjumlah 21 orang widyaiswara. Sampel yang digunakan adalah sampel jenuh, yaitu semua populasi diambil menjadi sampel dalam penelitian ini.

3. Teknik pengumpulan data dan pengembangan instrumen;

Teknik pengumpulan data dalam penelitian ini dengan menggunakan instrumen dalam bentuk quesioner. Quesioner disebar sebanyak 10 item pertanyaan lalu dihitung dengan menggunakan excel. Selain itu, peneliti 
menggunakan dokumentasi dengan mengumpulkan semua hasil presentasi interaktif dengan mentimeter yang dibuat oleh widyaiswara.

4. Teknik analisis data.

Penelitian ini dianalisa dengan menggunakan program excel dengan menghitung rata-rata kuesioner dengan mencari presentase widyaiswara yang memahami tentang aplikasi mentimeter dan penggunaannya.

\section{TEMUAN DAN PEMBAHASAN}

\section{A. Temuan}

Berdasarkan data yang didapat dari hasil penelitian kepada seluruh widyaiswara pada Balai Diklat Keagamaan Palembang mendapatkan hasil $85 \%$ widyaiswara telah memahami bagaimana membuat bahan ajar presentasi interaktif online dengan menggunakan aplikasi mentimeter. Penelitian ini dengan membagikan kuesioner dengan 10 pernyataan kepada widyaiswara tentang pemahaman mereka tentang aplikasi mentimeter. Untuk lebih jelasnya, dapat dilihat dari grafik berikut ini:

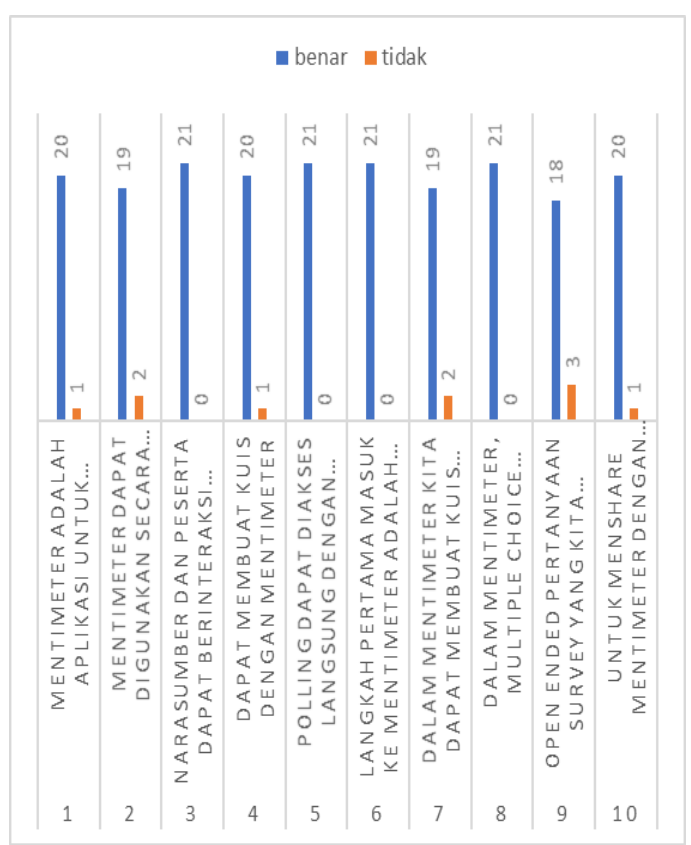

Grafik 1. Kompetensi Widyiswara tentang presentasi interaktif online dengan mentimeter
Dari hasil data diatas, maka dapat dikatakan secara garis besar widyaiswara Balai Diklat Keagamaan Palembang telah mengetahui aplikasi mentimeter.

Dari hasil penelitian didapat:

1. Pemahaman Widyaiswara Tentang Mentimeter

Untuk pernyataan nomor 1 sekitar $81 \%$ widyaiswara mengetahui bahwa aplikasi mentimeter adalah salah satu aplikasi presentasi interaktif online. Aplikasi mentimeter merupakan salah satu aplikasi yang dapat digunakan untuk mendesain presentasi interaktif secara online dan dapat digunakan secara langsung sehingga dapat menghidupkan suasana pembelajaran dalam pelatihan.

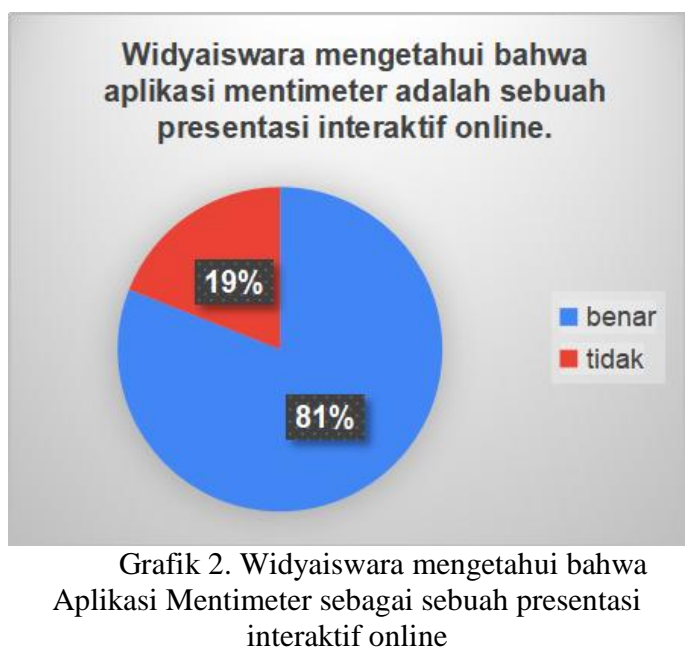

Untuk pernyataan nomor 2 , sekitar $86 \%$ widyaiswara mengetahui bahwa mentimeter tidak dapat digunakan secara offline. Mentimeter merupakan aplikasi online yang dapat membuat desain presentasi menjadi lebih interaktif dan menarik. 


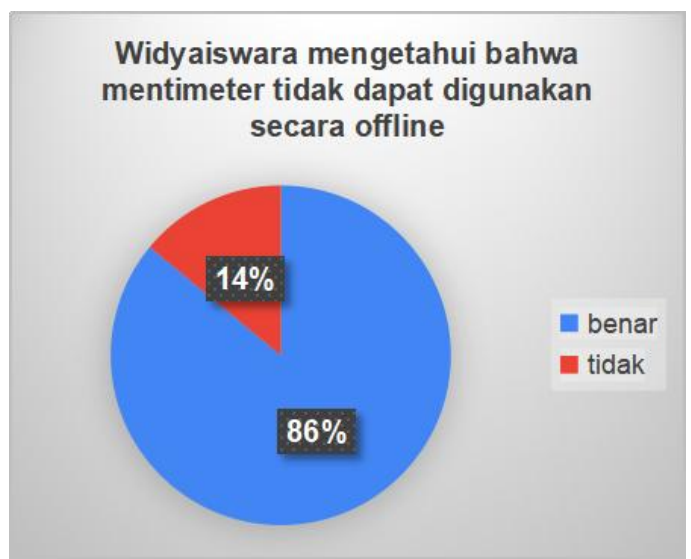

Grafik 3. Widyiswara mengetahui bahwa mentimeter tidak dapat digunakan secara offline

Sedangkan untuk pernyataan nomor 3 tentang manfaat mentimeter, yaitu dengan pernyataan widyaiswara mengetahui bahwa mentimeter dapat berinteraksi langsung dengan peserta mendapatkan hasil sekitar $90 \%$. Mentimeter tidak hanya digunakan sebagai presentasi interaktif online tetapi juga dapat digunakan sebagai alat untuk berinteraksi langsung dengan peserta pelatihan sehingga widyaiswara dapat memberikan penilaian terhadap peserta dan memantau konsentrasi peserta saat belajar.

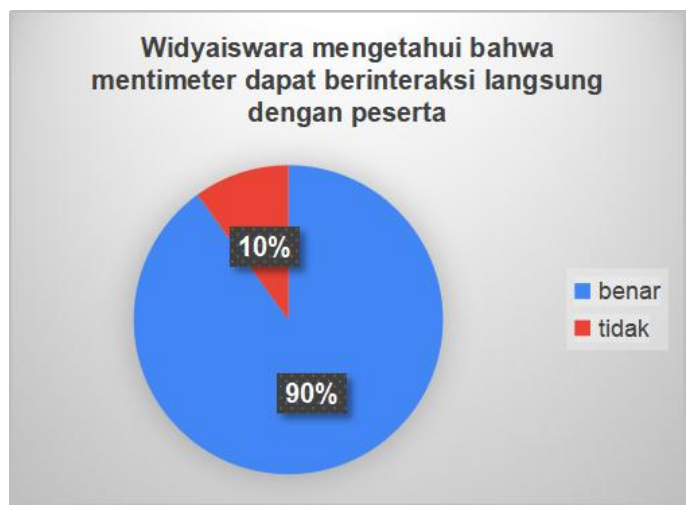

Grafik 4. Widyiswara mengetahui bahwa mentimeter dapat berinteraksi langsung dengan peserta

Pada pernyataan nomor 4 pengetahuan widyaiswara tentang aplikasi mentimeter dapat membuat kuis dengan mentimeter mendapat hasil $77 \%$. Dalam penggunaannya, mentimeter tidak hanya digunakan untuk menyampaikan materi tetapi dapat juga dijadikan kuis dalam pembelajaran secara langsung sehingga pembelajaran tidak monoton dan peserta menjadi lebih aktif.

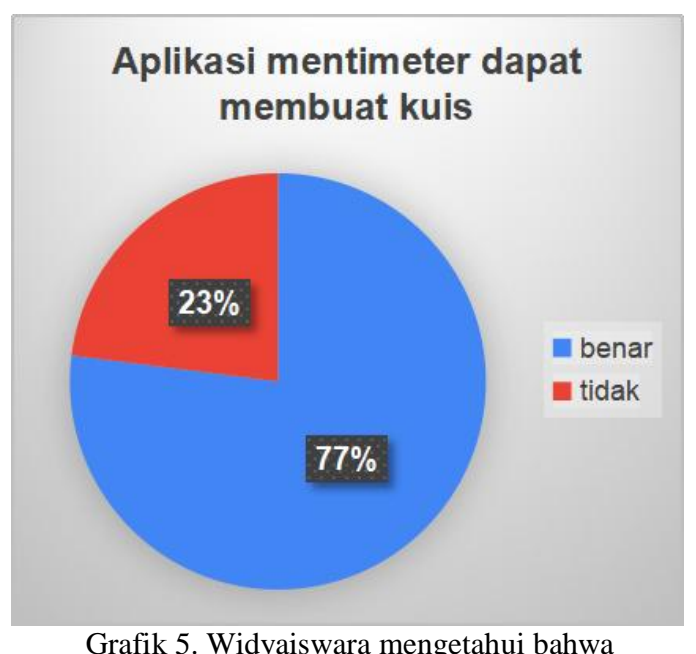
mentimeter dapat membuat kuis

Pernyataan nomor 5 mendapatkan hasil sekitar $95 \%$ widyaiswara mengetahui mentimeter dapat dijadikan polling yang dapat diakses secara langsung. Untuk mengetahui seberapa banyak atau besar pertanyaan yang ingin kita berikan kepada peserta, maka widyaiswara dapat membuat polling suara tentang sesuatu sehingga dapat diketahui secara langsung hasilnya, seperti pemilihan ketua kelas dalam mata diklat building learning commitment atau materi lainnya.

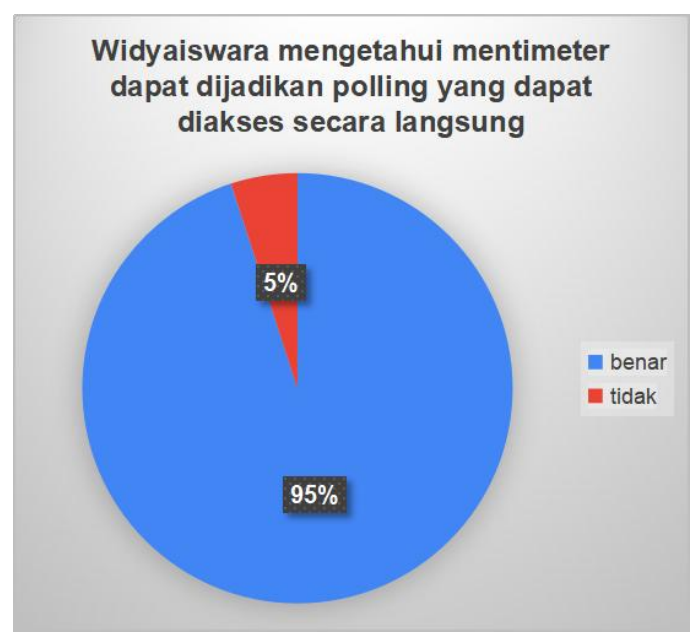

Grafik 6. Widyaiswara mengetahui mentimeter dapat dijadikan polling yang dapat diakses secara langsung

Pernyataan nomor 6 mendapatkan hasil sekitar $95 \%$ widyaiswara mengetahui 
langkah pertama untuk masuk ke mentimeter. Untuk masuk ke mentimeter, widyaiswara harus $\log$ in ke email atau google terlebih dahulu. Kita boleh membuat akun pada mentimeter terlebih dahulu atau langsung saja masuk dengan email.

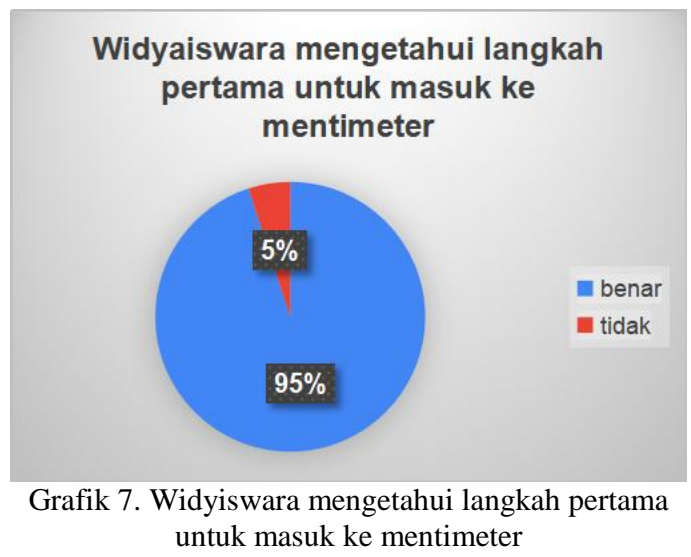

Dari hasil data yang didapat, sekitar $86 \%$ widyaiswara telah memahami apa itu fungsi mentimeter.

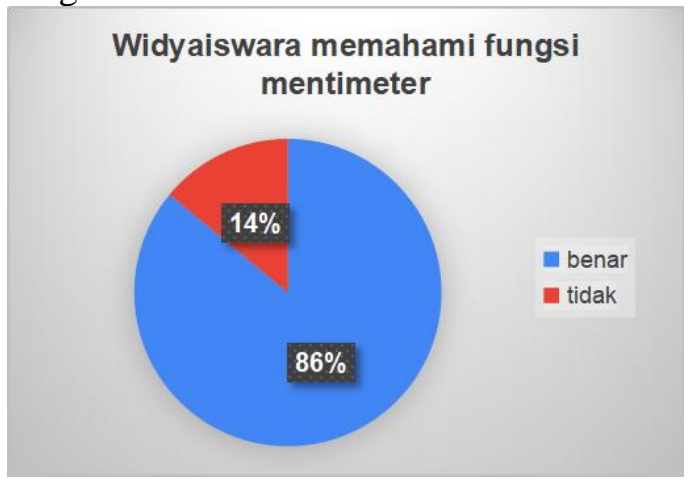

Grafik 8. Widyiswara memahami fungsi mentimeter

Dari data yang didapat sekitar $68 \%$ widyaiswara mengetahui fungsi penggunaan multiple choice pada mentimeter. Pada mentimeter, untuk membuat pertanyaan, ada bentuk multiple choice atau pilihan ganda. Bagian ini, dapat dijadikan widyaiswara untuk melakukan ujian dalam menilai kemampuan peserta setelah pelatihan dengan memberikan pertanyaan dan jawaban. Pada mentimeter untuk pilihan jawaban dapat berupa teks maupun gambar sehingga lebih menarik dan dapat dilihat secara langsung hasil jawaban peserta .

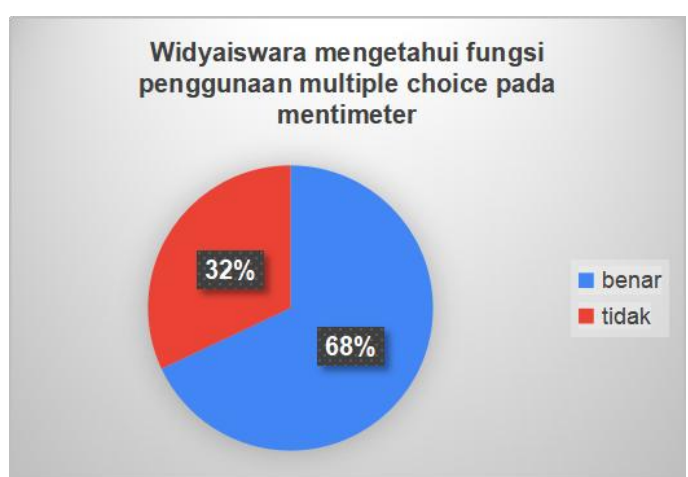

Grafik 9. Widyiswara mengetahui fungsi penggunaan multiple choice pada mentimeter

Untuk pernyataan nomor 9 didapat hasil sekitar $72 \%$ widyaiswara mengetahui penggunaan open ended dalam mentimeter. Open ended adalah sebuah penilaian online dengan memberikan pertanyaan dalam bentuk essai sehingga peserta dapat berkreasi dan berpendapat tentang pertanyaan yang diberikan widyaiswara saat presentasi ditayangkan.

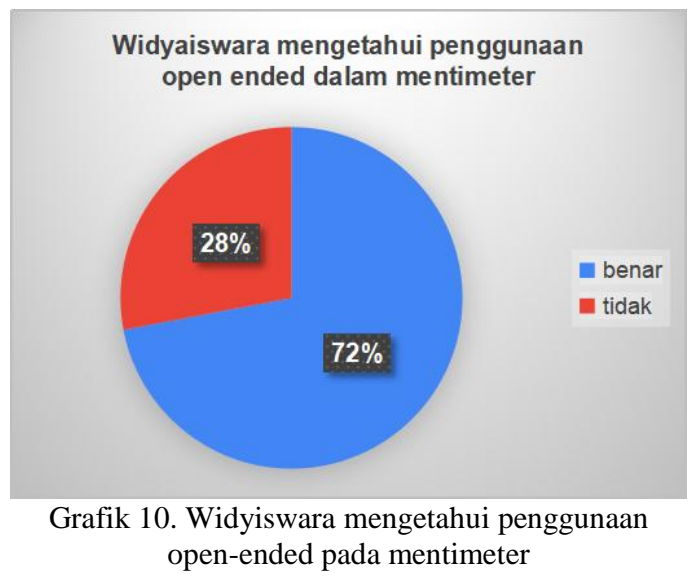

Pernyataan nomor 10 tentang pemahaman widyaiswara dalam mengetahui bagaimana cara membagikan mentimeter ke peserta mendapatkan hasil $81 \%$. Mentimeter berbeda dengan aplikasi presentasi lainnya yang bisa langsung ditayangkan, agar peserta pelatihan dapat terlibat langsung dalam materi widyaiswara maka widyaiswara harus memberikan kode agar dapat diakses dan bergabung dalam materi yang disampaikan. 


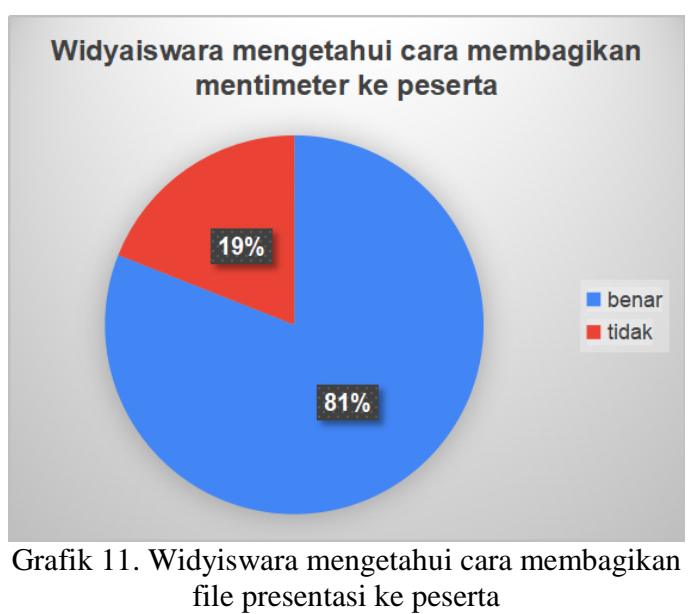

Dari hasil temuan diatas, dapat dikatakan keseluruhan widyaiswara dikatakan baik dalam mengenal aplikasi mentimeter walau belum memahami dengan baik bagaimana penggunaan mentimeter sebagai presentasi interaktif online dalam pelatihan jarak jauh atau e-learning.

\section{Kompetensi Widyaiswara dalam Menggunakan Mentimeter}

Selain kompetensi widyaiswara tentang aplikasi mentimeter, pemahaman widyaiswara dalam mengembangkan presentasi interaktif online masih beragam, dari hasil penelitian didapat:

1) Sebanyak $24 \%$ responden memahami penggunaan tentang aplikasi mentimeter,

2) Sebanyak $24 \%$ responden lupa dengan penggunaan aplikasi mentimeter.

3) Sebanyak $52 \%$ responden telah menggunakan aplikasi lain seperti powerpoint dan google slide. tabel berikut:

Untuk lebih jelas dapat dilihat dari

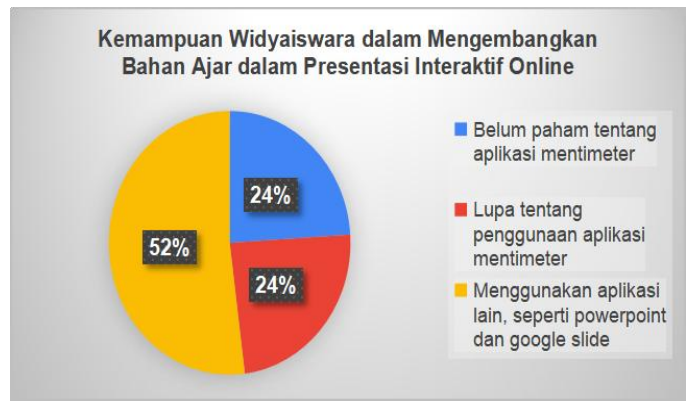

Grafik 12. Kemampuan Widyaiswara dalam Mengembangkan Bahan Ajar dalam Presentasi Interaktif Online

Dari hasil temuan diatas dapat dinyatakan bahwa sebagian besar widyaiswara telah mengetahui aplikasi mentimeter dan fungsinya sebagai salah satu aplikasi yang dapat digunakan untuk mendesain bahan ajar menjadi presentasi interaktif online. Namun, penggunaan secara khusus tentang mentimeter dalam pelatihan jarak jauh atau e-learning masih belum dipahami dengan sepenuhnya.

\section{B. Pembahasan}

Dari hasil temuan diatas, maka dapat katakan bahwa

1. Pemahaman Widyaiswara tentang mentimeter

Sebagian besar widyaiswara Balai Diklat Keagamaan Palembang telah mengetahui tentang aplikasi mentimeter yang merupakan sebuah presentasi interaktif online yang dapat digunakan widyaiswara sebagai alternatif dalam mengembangkan bahan ajar. Ini dapat dikatakan bahwa widyaiswara dapat mendesain dan mengembangkan bahan ajar dengan aplikasi ini. Selain itu, widyaiswara juga mengetahui bahwa mentimeter harus digunakan secara online sehingga membutuhkan jaringan untuk mengaksesnya.

Dengan aplikasi mentimeter juga, widyaiswara mengetahui bahwa mentimeter dapat dijadikan salah satu alternatif widyaiswara dalam pelatihan untuk berinteraksi langsung dengan peserta, memberikan penilaian maupun polling suara. Disini, peserta akan menjadi lebih aktif dalam pembelajaran, tidak hanya mendengarkan saja. Dengan demikian maka pelatihan akan lebih aktif, interaktif dan menyenangkan walau dilakukan secara online.

Dengan kata lain bahwa mentimeter tidak hanya sebagai media yang dapat digunakan untuk feedback atau umpan balik dari input yang diisikan oleh peserta melalui mentimeter. Presentasi akan lebih interaktif dengan tampilan dengan hasil feedback yang realtime (Eric, 2021). 
Widyaiswara dapat mengukur kemampuan peserta pelatihan baik diawal, tengah ataupun akhir dengan memberikan pertanyaan atau kuis dalam bentuk open-ended dimana peserta dapat dengan mudah menuangkan isi pikiran dan pendapatnya sehingga pembelajaran menjadi lebih interaktif. Seperti contoh, widyaiswara dapat melakukan pretest sebelum pembelajaran dimulai sehingga widyaiswara dapat mengetahui pengetahuan awal para peserta pelatihan. Selain itu, widyaiswara dapat memberikan kuis-kuis ditengah pembelajaran dengan maksud agar dapat menghibur peserta saat sedang jenuh sehingga peserta tidak akan bosan dengan materi yang disampaikan widyaiswara. Selanjutnya, di akhir pembelajaran widyaiswara juga dapat memberikan ujian akhir atau post test, widyaiswara dapat memberikan beberapa pertanyaan ujian untuk mengetahui sejauhmana hasil belajar peserta dalam pelatihan.

Selain sebagai kuis atau soal, widyaiswara juga mengetahui mentimeter dapat dijadikan alat polling atau pemungutan suara yang dapat diakses secara langsung sehingga dapat diketahui hasilnya secara langsung juga oleh widyaiswara dan peserta. Ini sangat menguntungkan widyaiswara dalam mengajar agar dapat mengetahui peserta yang aktif dalam belajar.

Sebagian besar widyaiswara juga telah memahami bagaiamana cara masuk atau login ke aplikasi mentimeter. Mereka dapat login melalui akun google dan langsung membuat presentasi.

Sebagian besar widyaiswara juga mengetahui fungsi mentimeter seperti penggunaan multiple choice atau pilihan ganda pada mentimeter. Untuk jawaban pilihan pada mentimeter dapat berupa teks, maupun gambar sehingga lebih menarik.

Dari hasil yang didapat widyaiswara juga telah mengetahui cara membagikan presetnasi mentimeter ke peserta pelatihan saat berinteraksi langsung sehingga dapat diketahui siapa saja yang aktif dan tidak aktif saat pembelajaran. Dengan cara ini, maka widyaiswara dapat mengetahui jalannya proses pembelajaran, dan peserta akan benar-benar belajar walau dalam kondisi jarak jauh atau e-learning.

2. Kompetensi widyaiswara tentang mentimeter

Dari hasil temuan diatas bahwa:

1) Sebanyak $24 \%$ responden telah memahami penggunaan tentang aplikasi mentimeter. Hal ini didapat dari kurangnya pengetahuan widyaiswara tentang aplikasi presentasi interaktif seperti mentimeter. Hal ini dibuktikan dari temuan penelitian Nurdin (2019) bahwa budaya literasi teknologi di kalangan widyaiswara pendidikan agama islam Balai Diklat Keagamaan tergolong rendah. Ini berarti, widyaiswara pada Balai Diklat Keagamaan masih rendah dan perlu ditingkatkan lagi.

2) Sebanyak $24 \%$ responden telah lupa dengan penggunaan aplikasi mentimeter. Hal ini dikarenakan aplikasi mentimeter perlu ketelitian dan kesabaran untuk mendesain karena mentimeter dilakukan secara online sehingga perlu jaringan internet untuk membuatnya. Selain itu, widyaiswara perlu mengulang untuk membuka mentimeter sehingga tidak lupa karena dalam aplikasi ini sedikit berbeda penggunaannya dengan powerpoint biasa. Dalam mentimeter, widyaiswara perlu memahami beberapa menu yang akan digunakan untuk mendesain presentasinya. Seperti contoh dalam menu type, widyaiswara dapat membuat presentasi dalam bentuk pertanyaan atau kuis baik multiple choice, word cloud, open ended, scales, dan question and answer. Jadi bentuk presentasi pada mentimeter memang agak sedikit berbeda dengan presentasi offline lainnya.

3) Sebanyak 52\% responden telah menggunakan aplikasi lain seperti powerpoint dan google slide. Hal 
ini disebabkan karena widyaiswara membutuhkan jaringan internet untuk membuatnya sehingga bila tidak ada internet maka tidak dapat membuka aplikasi ini. Selain itu untuk penggunaannya juga harus dilakukan secara online. Itulah kelemahan dari mentimeter dibandingkan dengan aplikasi offline seperti microsoft power point. Namun, mentimeter juga memiliki kelebihan yaitu widyaiswara dapat melakukan interaksi langsung dengan peserta sehingga widyaiswara dapat memantau kondisi dan kompetensi peserta selama pembelajaran.

Dari pembahasan diatas dapat dikatakan bahwa aplikasi mentimeter merupakan teknik atau cara menarik dan inovatif untuk mengembangkan dan menampilkan bahan ajar dalam bentuk presentasi interaktif online saat pelatihan khususnya pelatihan jarak jauh atau e-learning.

\section{PENUTUP}

\section{Simpulan}

Dari hasil pembahasan diatas, maka dapat disimpulkan bahwa kompetensi widyaiswara Balai Diklat Keagamaan Palembang dalam menggunakan mentimeter masih perlu ditingkatkan. Hal ini dikarenakan minimnya pengetahuan dan kemampuan widyaiswara dalam mengoperasikan mentimeter. Sebagian besar widyaiswara Balai Diklat Keagamaan Palembang hanya menggunakan aplikasi presentasi offline seperti powerpoint dalam mendesain bahan ajar. Selain itu, perlu adanya jaringan internet untuk membuka aplikasi ini. Namun, hasil yang didapat dari mentimeter memang lebih bagus dan menarik.

Dengan menggunakan mentimeter pada pelatihan jarak jauh, maka peserta pelatihan akan lebih senang dan semangat dalam belajar karena adanya interaksi langsung antara peserta dan widyaiswara sehingga keaktifan peserta pelatihan dapat terpantau.

\section{Rekomendasi}

Ada beberapa rekomendasi yang dapat diberikan yaitu sebagai berikut:

1. Pusdiklat Kementerian Agama

a. Memberikan pelatihan kepada seluruh widyaiswara tentang penggunaan TIK dalam pelatihan bagi widyaiswara.

b. Memberikan reward kepada widyaiswara yang berprestasi dalam bidan TIK atau membuat inovasi dalam pembelajaran

2. Balai Diklat Keagamaan Palembang

a. Memberikan pelatihan atau bimbingan teknis kepada widyaiswara Balai Diklat Keagamaan Palembang tentang penggunaan aplikasi mentimeter.

b. Mengembangkan profesionalitas widyaiswara dalam mengembangkan bahan ajar menjadi presentasi interaktif dalam pembelajaran jarak jauh dengan berbagai aplikasi online.

3. Bagi Widyaiswara

a. Mengembangkan bahan ajar pelatihan menggunakan aplikasi presentasi interaktif.

b. Menerapkan aplikasi mentimeter dalam pelatihan 


\section{DAFTAR PUSTAKA}

Ambar, T, S., \& Rosidah. (2003). Manajemen Sumber Daya Manusia. Penerbit Graha Ilmu: Yogyakarta

Eric. (2021). Template Mentimeter untuk Pembelajaran Jarak Jauh. Diakses pada Mei 2021 di https://www.erickunto.com/2020/04/template-mentimeter-untuk-pjj.html

Istianduru, A., \& Ptabowo A. (2020). Pelatihan Pembelajaran Inovatif Berbasis Mentimeter. Seminar Nasionla Hasil Pengabdian kepada Masyarakat. Hal. 251-256. e-ISSN: 2686-2964

Lembaga Administrasi Negara Republik Indonesia. (2016). Modul Diklat Kewiydaiswaraan Berjenjang Tingkat Tinggi. Pusat Pembinaan Widyaiswara. Jakarta

Nurdin. (2019). Urgensi Literasi Teknologi Informasi bagi Widyaiswara Pendidikan Agama Islam BDK Aceh Menghadapi Abad 21. Jurnal Pendidikan Sains Indonesia. Vol 7 (1). 55-53

Peraturan Menteri Pendayagunaan Aparatur Negara dan Reformasi Birokrasi Indonesia Nomor 22 Tahun 2014. Jabatan Fungsional Widyaiswara dan Angka Kreditnya. 5 Agustus 2014. Menteri Hukum dan Hak Asasi Manusia. Jakarta

Rivai, V. (2004). Manajemen Sumber Daya Manusia Untuk Perusahaan: Dari Teori ke Praktik. Jakarta: PT. Raja Grafindo

Rosidah, A. (2020). Membuat Presentasi Interaktif dan Survey Online dengan Aplikasi Mentimeter. Diambil kembali dari,

https://lpmpdki.kemdikbud.go.id/membuat-presentasi-interaktif-dan-survey-online-dengan-aplikas i-mentimeter/ 